\title{
TRAUMATIC CALLOSOTOMY
}

\author{
ARTHUR CUKIERT * - MONICA 8. HADDAD * - ANTONIO MU88I * \\ RAUL MARINO JR.*
}

\begin{abstract}
SUMMARY - In a 33 years-old epileptic 'woman 'with a traumatic impact to the vertex, clinical and radiological studies (skull X-R, CT and MRI) disclosed an extensive, callosal section under the topography of the falx, associated to frontonasal contusions. There was a significant improvement in the epileptic syndrome. No interhemispheric disconnection syndrome could be determined, which is compatible with the posterior regions of the corpus callosum having been spared. This is, to the best of our knowledge, the most extensive callosal injury documented by MRI to date.
\end{abstract}

KEY WORDS: epilepsy, head trauma, callosotomy, diffuse axonal injury.

\section{Calo\&otomia-traumática
Calogpotomia-traumatica}

RESUMO - Uma paciente epiléptica jovem foi vítima de queda de certa altura após crise tônico-clônica generalizada. Foi admitida em coma no Setor de Emergência. Sua investigação clínico-radiológica mostrou presença de hematomas interhemisféricos, extensa secção traumática do corpo caloso e contusões fronto-basais. A despeito de hemiparesia residual, sua investigação neuropsicológica não mostrou sinais de desconexão hemisférica, compatível à integridade da região do esprênlo «ao exame de RMN. Após o trauma, a paciente, apresentou grande melhora da síndrome epiléptica. O papel relativo de cada uma das lesões traumáticas é difícil de ser inferido, em se tratando de lesão cerebral múltipla. O provável mecanismo fisiopatológico deve incluir impacto direto do corpo caloso contra a foice, além de mecanismos de aceleração/ desaceleração.

PALAVRAS-CHAVE: epilepsia, trauma craniano, calosotomia, lesão axonal difusa.

Callosal lesions can be derived from both surgical procedures and trauma. Surgical callosal sections as a modality of treatment of refractory seizures are usually not associated to other brain abnormalities ${ }^{3}$. Traumatic lesions of the corpus callosum, which are frequent in diffuse axonal injuries, are very often accompanied by other central nervous system lesions 8 .

Traumatic callosal contusions are usually incomplete and small, and result mainly from an acceleration/deceleration mechanism, rather than of a direct impact. We present a case where an extensive traumatic callosal injury, probably caused by a direct fabc impact, was documented.

\section{CASE REPORT}

MCS, a 33 years old woman, was admitted to the emergency room immediatly after falling from a window due to a tonic-clonic seizure, from which a direct impact to the vertex resulted. She had been treated for complex partial secondarily generalized seizures for 5 years and was taking phénobarbital lOOmg daily, with a seizure frequency of $2 /$ week. At admission, she had a Glasgow Coma Score of 7 and a massive right hemiparesis. Skull X-rays showed

* Department of Neurology, University of São Paulo School of Medicine.

Dr. Arthur Cukiert - Rua Baltazar da Veiga 367 apto 151 - Ofy510 São Paulo SP - Brasil. 

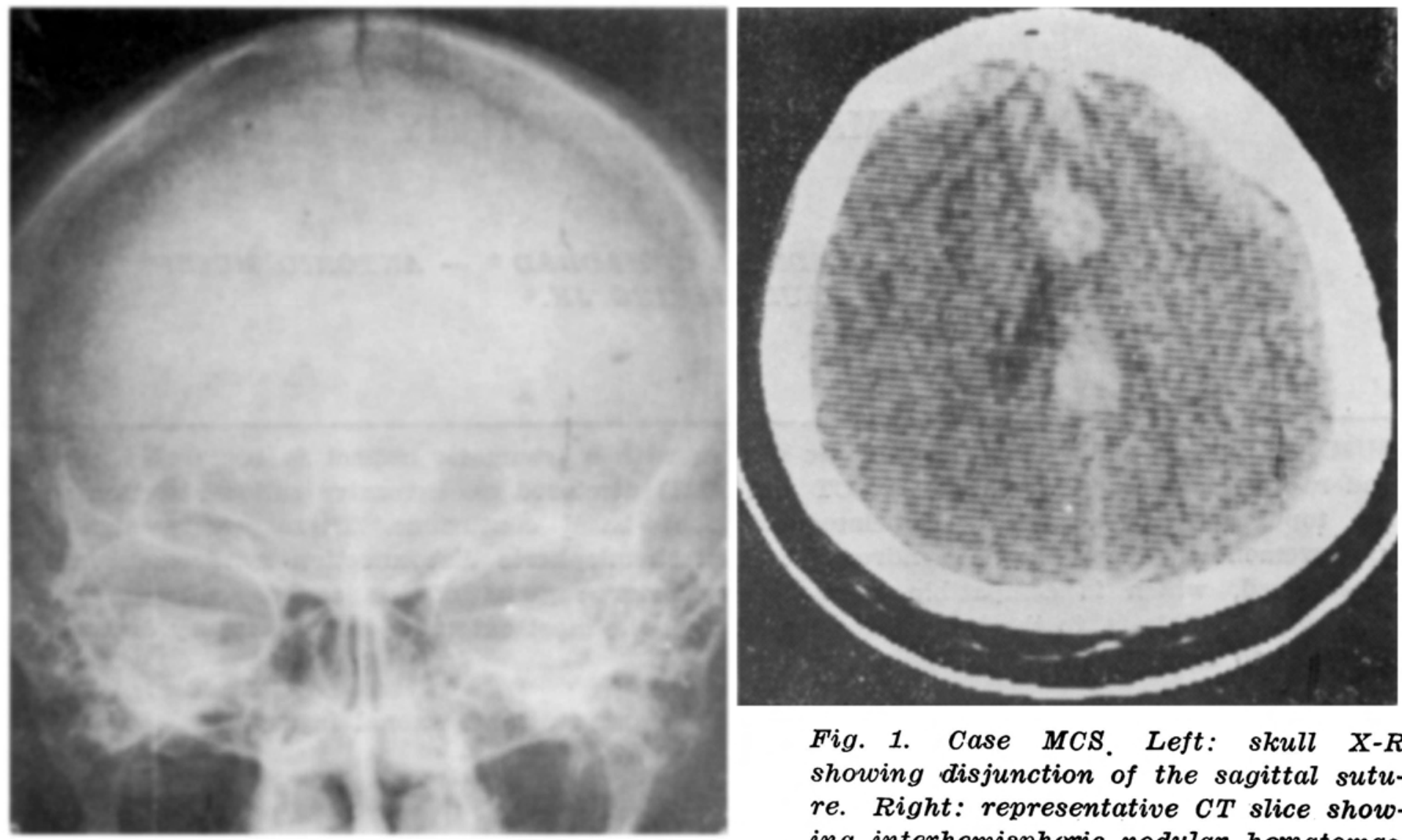

Fig. 1. Case MCS. Left: skull $X-R$ showing disjunction of the sagittal suture. Right: representative CT slice showing interhemispheric nodular hematomas.

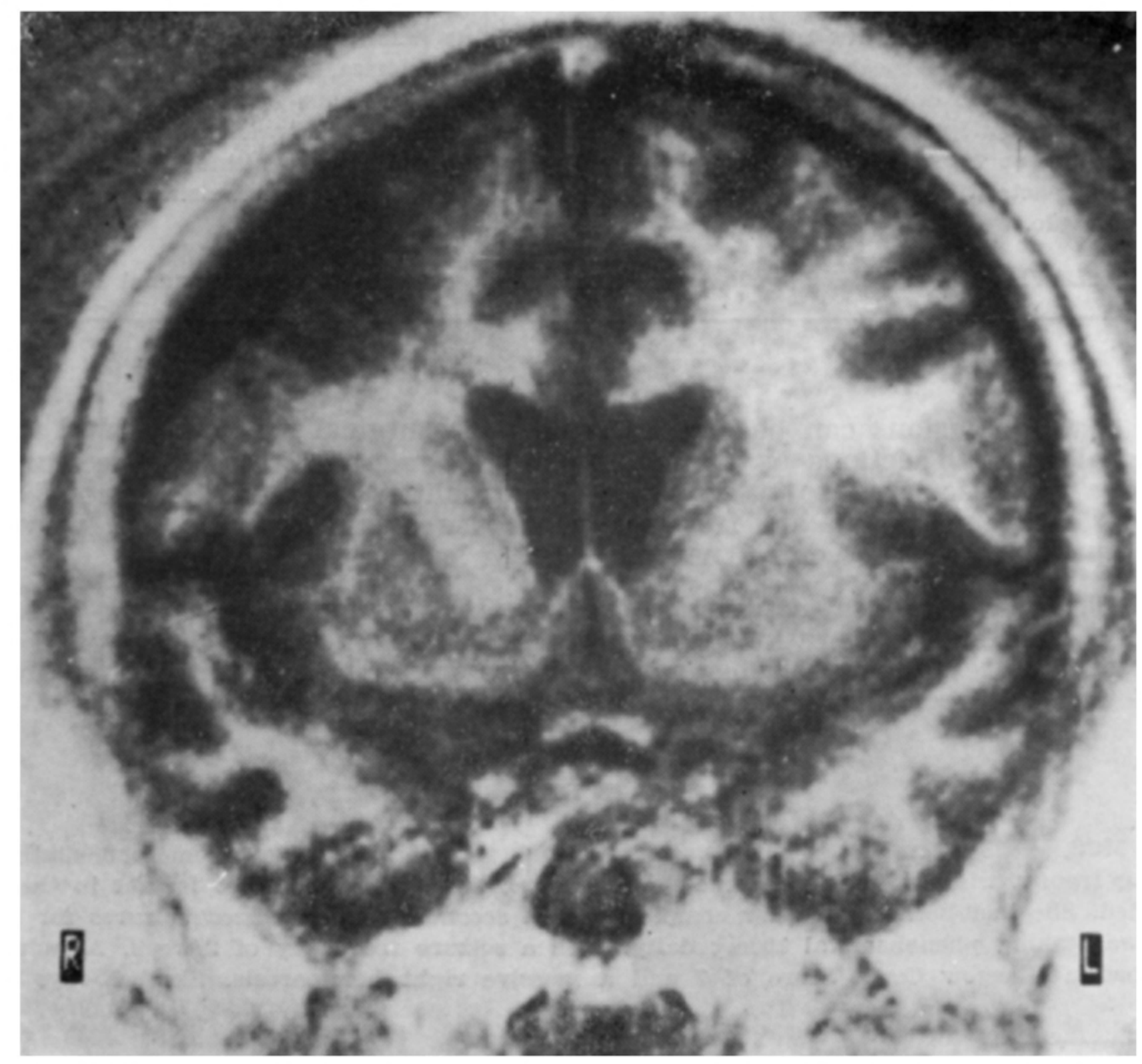

Fig. 2. Case MCS. Coronal MRI showing the completeness of callosal section. 
disjunction of the sagittal suture and CT imaging disclosed two nodular inter hemispheric hematomas at the topography of the cingulum and corpus callosum (Fig. 1). The patient progressively improved and was released from the hospital after two weeks with a slight right hemiparesis and aphasia. Despite the mantainance of her habitual antiepileptic drug regimen, no generalized seizures occurred along the following five months. MRI obtained six months after trauma showed complete section of the corpus callosum below the topography of the falx and frontobasal contusions (Figs. 2 and 3 ). BEfG recording showed independent bilateral parasagittal and right temporal spikes. Neuropsychological evaluation after five months did not detect signs of interhemispheric disconnection.

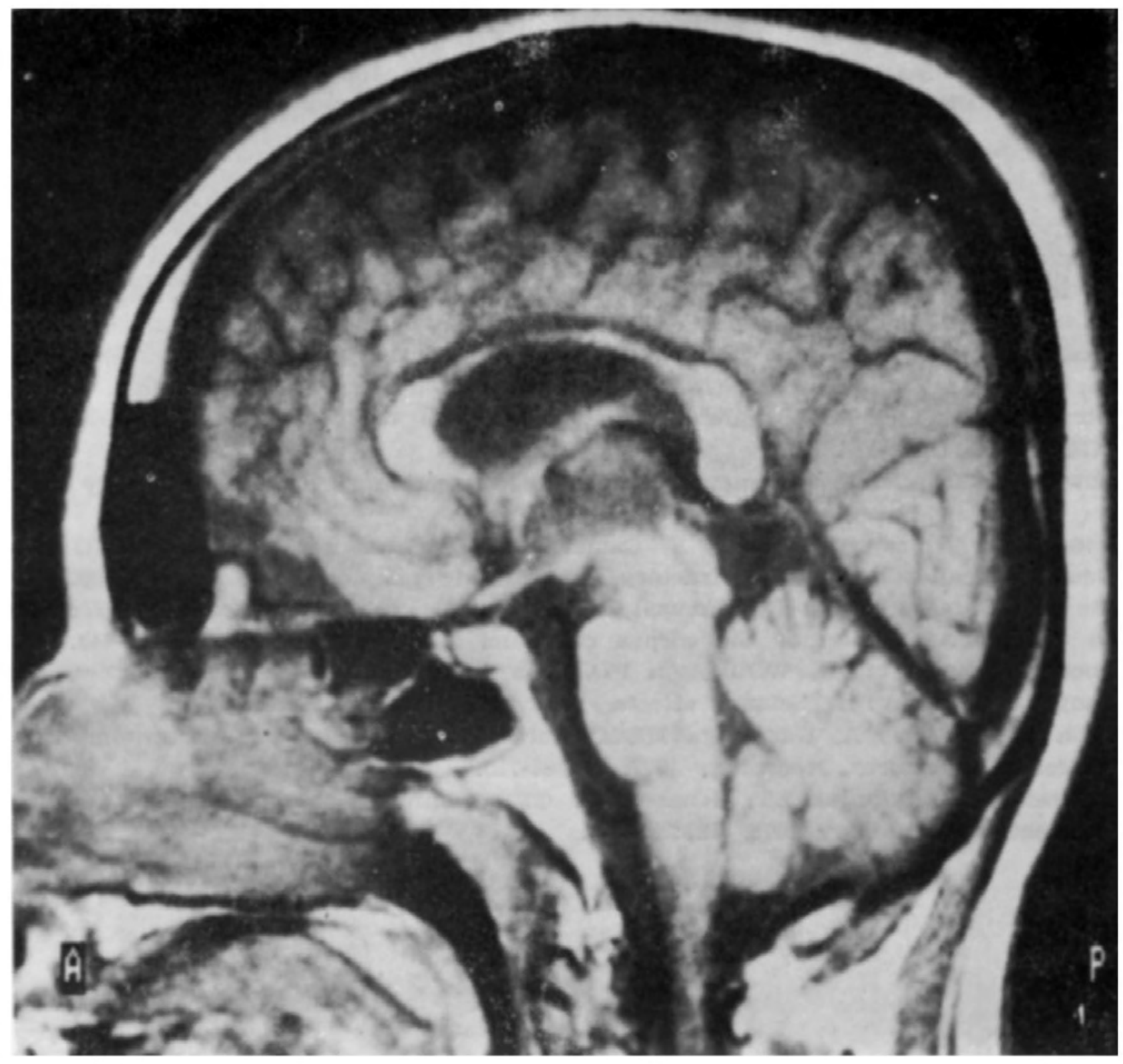

F'ig. 3. Case MCS. Mid-sagittal MRI showing the extension of callosal section.

\section{COMMENTS}

This is, up to our knowledge, the most extensive traumatic callosal lesion documented by MRI to date.

Diffuse axonal injury is one of the most common type of head injury ${ }^{1}$. Small white matter and brain stem hemorrhages and contusions are characteristic of this type of trauma.

The extent of the callosal injury hereby described coincides exactly with the topography of the falx. Despite the fact that diffuse axonal injuries are typically caused by acceleration/deceleration forces ${ }^{2}$, a direct impact to the vertex and a brain contusion against the falx might have accounted for this rare and extensive type of callosal injury observed in our patient. As is also common in diffuse axonal injuries, multiple contusions were associated to the callosal section 9. 
Callosal sections have been used for the control of medically intractable seizures 5.7. $m$ such cases, open or stereotactic procedures usually create isolated callosal injuries and a marked reduction in secondarily generalized seizures is obtained in almost all patients. This patient disclosed a clearcut reduction in seizure frequency but, unfortunetely, the result of this "traumatic callosotomy" cannot be analyzed due to the concomitant presence of other cortical lesions that could be associated with a modification of the previous focus activity.

Interhemispheric disconnection syndromes have rarely been described after incomplete callosal sections ${ }^{4}$, especially when its posterior regions remained intact 6. No interhemispheric syndrome could be documented one year after injury in the present case.

Aeknoledgements - This study was supported by the State of Sao Paulo Research Foundation (FAPESP), FINEP and Institute of the Laboratories of Medical Research (L\#IM).

\section{RE FER E N C ES}

1. Adams JH, Graham DI, Murray LS, Scott G. Diffuse axonal injury due to non-mis3ile head injury in humans: an analysis of 45 cases. Ann Neurol 1982, 12:557-563.

2. Gen\&relli TA, Thibault LE, Adams JH, Graham DI, Thompson CJ, Mar cine in RP. Diffuse axonal injury and traumatic coma in the primate. In Dacey RG Jr, Winn HR, Rimel RW, Jane JA (eds): Trauma of the CNS. New York: Raven Press, 1985, p 169-193.

3. Gentry LR, Thompson B, Godersky JC. Trauma to the corpus callosum: MRI features. A J N R 1988, 9:1129-1138.

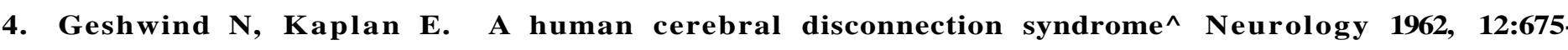
685.

5. Marino R Jr, Radvany J. Huck F, Camargo CHP, Gronich G. Selective EEG guided microssurgical callosotomy for refractory generalized epilepsy. Surg Neurol 1990, 34:219-228

6. Risse GD, Gates $J$, Lund $G$, Maxwell $R$, Rubens A. Interhemispheric transfer in patients with uncomplete section of the corpus callosum. Arch Neurol 1989, 46:437-444.

7. Spencer SS, Spencer DD, Williamson PD, Sass K, Novelly RA, Mattson MD. Corpus callosotomy for epilepsy: I. Seizure effects. Neurology 1988, 38:19-24.

8. Wilson DH, Reeves A, Gazzaniga MDM, Culver C. Cerebral commissurotomy for control of intractable seizures. Neurology 1977, 27:708-715.

9. Zimmerman RA, Rilaniuk LiT, Genarelli T. CT scanning of sheering injuries of the cerebral white matter. Radiology 1978, 127:398-396. 